\title{
Nocturnal Penile Tumescence Studies in Spinal Cord Injured Males
}

\author{
Sofjan Lamid, M.D.* \\ Department of Physical Medicine and Rehabilitation, Medical College of Wisconsin, \\ Milwaukee, Wisconsin, U.S.A. Associate Professor, Louisiana State University \\ Medical Center, Louisiana Rehabilitation Institute, New Orleans, Louisiana, \\ U.S.A.
}

\section{Summary}

Traditional methods of evaluating sexual function in disabled individuals using neurological examinations, interviews, and psychological screening has been well established. A patient's ability to have erections and ejaculations are recorded through interviews with the patient and his partner. Therefore, to obtain a more objective view of the patient's sexual function, we used a nocturnal penile tumescence monitor in 12 tetraplegics and 12 paraplegics. Patients were interviewed for sexual histories before and after the injury. Their penile size was monitored during sleeping time using two strain gauges attached to each end of the penile shaft. The bridge output from these strain gauges was amplified to a single channel recorder. The spontaneous increase of penile circumference and its duration was recorded. The result showed that: 1. tetraplegics had a greater increase of penile size and longer duration of erection than paraplegics, 2. there is no correlations between incompleteness of spinal lesion and erection, 3. there is no correlation between the presence of bulbocavernosus reflex and erection, and 4. there is no correlation between sex dreams and erections. Key words: Penile tumescence; Spinal cord injury.

\section{Introduction}

Most spinal cord injured (SCI) patients survive the acute phase of their injury, but become tetraplegic or paraplegic resulting in paralysis of the limbs together with loss of bowel, bladder and sexual functions. Some of these patients indicate that, if they had a choice, they would rather have a return to normal sex life than the return of their motor functions. (Comarr and Vigue, 1978). For these patients erectile dysfunction is a frustrating condition.

Traditional methods of sexual function evaluation in disabled individuals using neurological examinations, interviews and psychological screening has been established (Comarr and Vigue, 1978; Bors and Comarr, 1960; Comarr and

^ Editor, Journal of American Paraplegia Society. Current Address: Sofjan Lamid, MD, Louisiana Rehabilitation Institute, 1532 Tulane Avenue, New Orleans, LA 70140, U.S.A. 
Vigue, 1978; Hohmann, 1972; Berkman et al., 1978). However, a patient's capability to have an erection was recorded through interviews with the patient and his partner. Therefore, much of the current data for sexual function evaluation in SCI is retrospective. A nocturnal penile tumescence monitor (NPTM) has been used during the past few years as an objective method in diagnostic evaluation of the erectile capability of the penis in normal volunteers and individuals with sexual dysfunction (Karacan et al., 1972; Karacan et al., 1975; Karacan et al., 1978; Kenepp and Gonich, 1979; Leyson and Powell, 1982). The purpose of this paper is to objectively evaluate the erectile capability of SCI patients using NPTM and to measure changes of penile tumescence in relation to the level of spinal cord injury, completeness of the lesion, and the presence of the bulbocavernosus reflex.

\section{Material and Methods}

\section{Patients}

Twelve tetraplegics and 12 paraplegics were included in the study. They were all hospitalised male patients and their ages ranged from 20 to 57 years (mean $=$ $31.4)$, see Table 1 . Some of these patients were recently injured subjects $(0.6$ months post-injury) who entered the study as part of a work-up for a sexual function evaluation before sexual counselling. Some other patients were old SCI subjects (more than 12 months post-injury) who entered the study because they requested implantation of a penile prosthesis.

Table 1 Level of injury and completeness/incompleteness of lesion

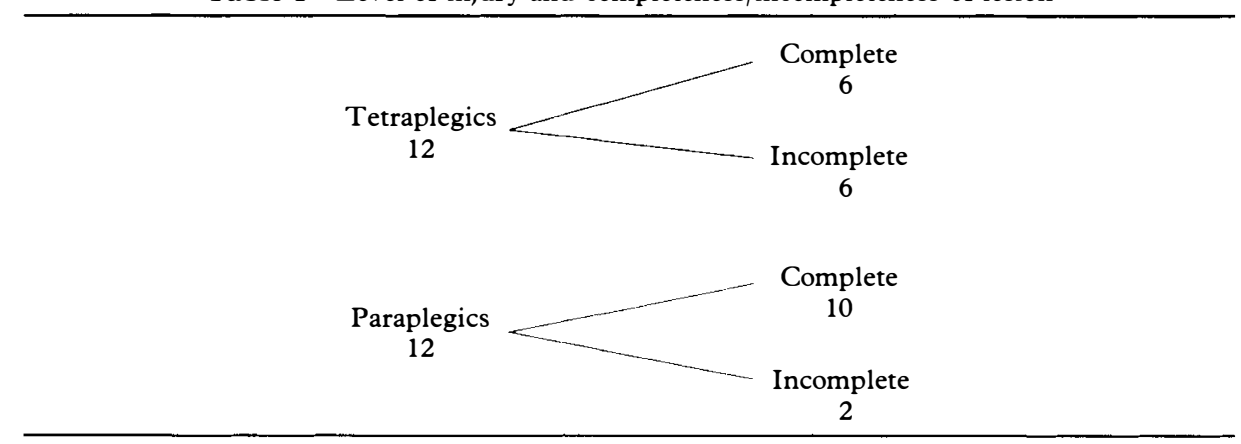

All subjects were interviewed for sexual histories before and after the injury. A complete physical and neurological examination was performed in order to determine the level of spinal cord injury, the completeness of spinal lesion and the presence of a bulbocavernosus reflex. Urological evaluation included: examination of the penis, the presence of psychogenic and reflexogenic erections, and the types of urinary drainage patients used. Psychogenic erections were assessed by using visual stimuli and reflexogenic erections were determined by stimulation of the genital area, such as touching the penis and the scrotum.

\section{Methods}

We used AMS (American Medical System) NPTM to measure changes in the 
Table 2 Concurrent medications during the evaluation period

\begin{tabular}{lc}
\hline Medications & Number of patients on medication \\
\hline Diazepam & 12 \\
Dantrolene & 3 \\
Bethanechol & 4 \\
Baclofen & 2 \\
Methenamine Mandelate & 6 \\
Ascorbic Acid & 8 \\
\hline
\end{tabular}

patient's penile size during sleep. Two strain gauges were placed on each end of the penile shaft; one strain gauge was attached to the base of the penis and the other one was positioned at the tip just behind the glans. The bridge output from these strain gauges was amplified to a single channel strip recorder. In previous studies (Karacan et al., 1972; Karacan et al., 1975; Karacan et al., 1978), NPT was monitored simultaneously with electroencephalography (EEG) and electro-oculography (EOG). However, recent published data indicate that EEG and EOG events during sleep were not necessarily associated with NPT (Leyson and Powell, 1982). Like other investigators (Kenepp and Gonick, 1979; Leyson and Powell, 1982), we used only NPTM for evaluating erectile capability in our patients. Patients were placed in bed late in the afternoon, and NPT was recorded for 15 hours. Since all subjects had paralysed lower extremities, artifacts on recording paper due to patient's movements were avoided. All events at night, such as changing of patient's position and intermittent catheterisation by the nurse, were recorded properly in order to minimize artifacts. NPT's were repeated on those patients with no penile expansion. In addition, patients were interviewed the following morning regarding the presence of sex dreams during NPTM.

The number of erections at night, the duration of each episode expressed in minutes, and the expansion of penile circumference measured in $\mathrm{mm}$ were tabulated for each patient. The data was collected and the relationship between NPT and the level of spinal cord injury, the completeness of the spinal lesion, and the presence of bulbocavernosus reflex was analysed statistically using analysis of variance (Woolf, 1968).

Concurrent medications at the time of NPT evaluation that may affect erectile function were recorded (Table 2).

\section{Results}

The mean duration of erectile episode was 14.9 minutes for tetraplegics and 4.75 minutes for paraplegics (Table 3 ). The difference was statistically significant $(P<0.01)$. Table 4 shows the mean increase of penile circumference which was $13.3 \mathrm{~mm}$ for tetraplegics and $4.25 \mathrm{~mm}$ for paraplegics. The difference was highly significant $(P<0.01)$. Furthermore, it is shown on Table 4 that the patients with incomplete spinal lesion had more penile expansion than those with complete lesion, but, the difference was statistically insignificant. There was no correlation between NPT and the presence of the bulbocavernosus reflex and the presence of sex dreams. Also, there was no correlation between NPT and the types of urinary drainage patients used and the presence of reflexogenic 
Table 3 Relationship between duration of erectile episode and level of spinal injury

\begin{tabular}{lcccc}
\hline $\begin{array}{l}\text { Level of } \\
\text { spinal injury }\end{array}$ & $\begin{array}{c}\text { Number of } \\
\text { patients }\end{array}$ & $\begin{array}{c}\text { Mean duration of } \\
\text { erectile episodes } \\
\text { (Minutes) }\end{array}$ & F value & $\begin{array}{c}\text { Level of } \\
\text { significance }\end{array}$ \\
\hline $\begin{array}{l}\text { Tetraplegia } \\
\text { Paraplegia }\end{array}$ & 12 & 14.9 & 8.92 & P $<0.01$ \\
\hline
\end{tabular}

Table 4 Relationship between penile tumescence and level of spinal injury, completeness of spinal lesions, etc.

\begin{tabular}{|c|c|c|c|c|}
\hline & $\begin{array}{l}\text { Number of } \\
\text { patients }\end{array}$ & $\begin{array}{c}\text { Mean increase } \\
\text { of penile } \\
\text { circumference }(\mathrm{mm}) \\
\text { and range }\end{array}$ & $F$ value & $\begin{array}{c}\text { Level of } \\
\text { significance }\end{array}$ \\
\hline $\begin{array}{l}\text { Tetraplegia } \\
\text { Paraplegia }\end{array}$ & $\begin{array}{l}12 \\
12\end{array}$ & $\begin{array}{r}13 \cdot 3(2-25) \\
4 \cdot 25(0-16)\end{array}$ & $9 \cdot 35$ & $P<0.01$ \\
\hline $\begin{array}{l}\text { Complete spinal lesion } \\
\text { Incomplete spinal lesions }\end{array}$ & $\begin{array}{r}16 \\
8\end{array}$ & $\begin{array}{r}7 \cdot 31(0-18) \\
11 \cdot 75(2-25)\end{array}$ & $1 \cdot 49$ & N.S. \\
\hline $\begin{array}{l}\text { Positive B.C. Reflex } \\
\text { Negative B.C. Reflex }\end{array}$ & $\begin{array}{l}11 \\
13\end{array}$ & $\begin{array}{c}10 \cdot 9(2-25) \\
7 \cdot 0(0-16)\end{array}$ & $1 \cdot 27$ & N.S. \\
\hline $\begin{array}{l}\text { Presence of sex dreams } \\
\text { Absence of sex dreams }\end{array}$ & $\begin{array}{r}14 \\
8\end{array}$ & $\begin{array}{c}10 \cdot 14(4-25) \\
8 \cdot 0 \quad(0-25)\end{array}$ & $0 \cdot 30$ & N.S. \\
\hline $\begin{array}{l}\text { Indwelling Foley Cath. } \\
\text { External condom drainage }\end{array}$ & $\begin{array}{r}6 \\
16\end{array}$ & $\begin{array}{l}8 \cdot 0 \quad(0-25) \\
8 \cdot 06(2-25)\end{array}$ & $0 \cdot 10$ & N.S. \\
\hline $\begin{array}{l}\text { Presence of reflex erect. } \\
\text { Absence of reflex erect. }\end{array}$ & $\begin{array}{r}8 \\
15\end{array}$ & $\begin{array}{r}13 \cdot 13(4-25) \\
7 \cdot 07(0-18)\end{array}$ & $2 \cdot 76$ & N.S. \\
\hline
\end{tabular}

Table 5 Classification of erectile dysfunction in relation to level of spinal injury

\begin{tabular}{lcc}
\hline \multirow{2}{*}{$\begin{array}{l}\text { Classification of erectile } \\
\text { dysfunction }\end{array}$} & \multicolumn{2}{c}{ Level of spinal injury } \\
\cline { 2 - 3 } Full erect & Tetraplegics & Paraplegics \\
Partial erection & $7\left(58 \cdot 3 \%_{0}\right)$ & $1(8 \cdot 3 \%)$ \\
No erection & $2\left(25_{0}^{\circ}\right)$ & $5(41 \cdot 7 \%)$ \\
\hline & $2\left(16 \cdot 7_{0}^{\circ}\right)$ & $6(50 \%)$ \\
\hline
\end{tabular}

erection. Two patients with incomplete spinal lesion had psychogenic erections.

In addition, we analysed the data on penile tumescence by placing the patients in three groups according to their erectile dysfunction (Karacan et al., 1978; Leyson and Powell, 1982):

Group 1-Patients with full erections who at least had one erectile episode with a penile expansion of $16 \mathrm{~mm}$ or more and with duration of more than 22 minutes.

Group 2-Patients with partial erections, who had penile expansion between $2 \mathrm{~mm}$ and $16 \mathrm{~mm}$ and its duration of less than 22 minutes.

Group 3-Patients with no erections, who had less than $2 \mathrm{~mm}$ penile expansion.

Table 5 shows the number of tetraplegics and paraplegics who had full, partial and no erections. There were more tetraplegics $(58.3 \%)$ with full erections 
and more paraplegics $(50 \%)$ with no erections. Old injured SCI patients (more than 12 months post-injury) who had no erections were advised to have penile prosthesis. The other patients were given sexual counselling.

\section{Discussion}

The use of NPTM as additional clinical data for the objective evaluation or erectile dysfunction is well established (Karacan et al., 1972; Karacan et al., 1975; Karacan et al., 1978; Kenepp and Gonick, 1979; Leyson and Powell, 1982). However, a recent publication disputed the usefulness of NPTM in sexual function evaluation (Marshall et al., 1981). We doubted the validity of this latest publication because the authors had only five cases to refute the value of NPTM. Authors of previous studies (Karacan et al., 1972; Karacan et al., 1975; Karacan et al., 1978; Kenepp and Gonick, 1979; Leyson and Powell, 1982) had more than 300 subjects (normal volunteers and patients with sexual dysfunction) to validate the usefulness of NPTM in establishing the diagnosis of erectile dysfunction. We agree with other investigators (Kenepp and Gonick, 1979; Leyson and Powell, 1982), that artifacts should be identified and omitted from the data. With some limitation, NPTM can contribute as a diagnostic tool for sexual dysfunction in males.

Our results show that tetraplegics had a longer duration of erectile episode and more penile expansion that those of paraplegics. Also, there were more tetraplegics with full erections and more paraplegics with no erectile episodes. These findings were consistent with retrospective surveys (Comarr and Vigue, 1978; Bors and Comarr, 1960). Contrary to previous studies with interviews (Comarr and Vigue, 1978; Bors and Comarr, 1960), our findings indicate that there are no differences of NPT between patients with complete and incomplete spinal lesion. Furthermore, some investigators placed great emphasis on the importance of bulbocavernosus reflex in sexual function evaluation of disabled individuals (Ertikin and Reel, 1976). We agree with Karacan et al. (Karacan et al., 1978) that the presence of the bulbocavernosus reflex was not associated with increased penile tumescence. In addition, in our patients NPT was not related to the types of urinary drainage used and it was not associated with the presence of sex dreams and reflexogenic erections. The effect of medications on NPT was difficult to evaluate in our patients since many of them were on multiple drugs during the monitoring period.

\section{Conclusion}

We concluded that NPTM is more valuable than retrospective interviews in establishing the objective diagnosis of sexual dysfunction in SCI patients, therefore, it is useful in determining the proper course of treatment for sexual disability in these patients.

\section{Résumé}

Les méthodes traditionnelles d'évaluer la fonction sexuelle chez les individus incapacités à l'aide d'examens neurologiques, d'interviews, d'examens psychologiques ont été bien établies. La capacité 
d'un malade d'avoir des érections et des éjaculations est enregistrée au moyen d'interviews avec le malade et avec sa compagne. Ainsi, pour obtenir une vue plus objective de la fonction sexuelle du malade, nous avons employé un enregistreur nocturne de tumescence pénile chez 12 tétraplégiques et 12 paraplégiques. On a interviewé les malades au sujet des histoires sexuelles avant et après la blessure. On a enregistré leur grandeur pénile pendant le temps de sommeil à l'aide de deux extensiomètres attachés à chaque extrémité de la tige pénile. La sortie de pont depuis ces extensiomètres était amplifiée vers un enregistreur à canal unique. L'accroissement spontané de la circonférence pénile et sa durée étaient enregistrés. Le résultat montrait que: 1. les tétraplégiques avaient un plus grand accroissement de grandeur pénile et une plus longue durée d'érection que les paraplégiques, 2. il n'y a pas de correlation entre le degré jusqu'où la lésion vertébrale n'est pas complète et l'érection, 3. il n'y a pas de correlation entre la présence du réflexe bulbocaverneux et l'érection, et 4 . il n'y a pas de correlation entre les rêves sexuels et les érections.

\section{Kurzverfassung}

Die herkömmlichen Methoden, die Geschlechtsfunktion bei Untauglichen mittels neurologischer Untersuchungen, Interviews, und psychologischer Befragung auszuwerten, haben sich schon gut bewiesen. Die Fähigkeit eines Patienten, Erektionen und Ejakulationen zu haben, wird durch Interviews mit dem Patienten und seiner Genossin aufgeschrieben. Also, um eine objektivere Übersicht über die Geschlechtsfunktion von einem Patienten zu bekommen, haben wir einen nächtlichen Penistumeszierungsanzeiger bei 12 Tetraplegischen und 12 Paraplegischen angewendet. Man hat die Patienten über ihre geschlechtliche Geschichte vor wie nach der Verletzung interviewt. Ihre Penisgrösse wurde während der Schlafzeit mit Hilfe von zwei an jedes Ende des Penisstengels befestigten Dehnungsmessern überwacht. Der Brückenausgang von diesen Dehnungsmessern wurde nach einem Einzelkanalanzeiger verstärkt. Die spontane Vergrösserung des Peniskreisumfangs und ihre Dauer wurden aufgezeichnet. Das Ergebnis zeigte: 1. dass Tetraplegische mehr Vergrösserung der Penisgrösse und eine längere Erektionsdauer hatten als Paraplegische, 2. dass es keine Korrelation zwischen Unvollständigkeit der Rückengratverletzung und Erektion gibt, 3. dass es keine Korrelation zwischen Anwesenheit des Bulbokavernreflexes und Erektion gibt, und 4, dass es keine Korrelation zwischen geschlechtlichen Träumen und Erektion gibt.

NB. In German the word that would never be taken out of its clause and put before the numbers. I have therefore inserted it after each number, as is the normal practice in German.

\section{References}

Berkman AH, Weismann R, Frielich MH 1978 Sexual adjustment of SCI veterans living in the community. Archives of Physical Medicine and Rehabilitation 59:29-33.

Bors E, ComarR EA 1960 Neurological disturbances of sexual function with special references to 529 patients with spinal cord injury. Urol. Surv. 10:191-214.

ComARR EA, Vigue MS 1978 Sexual counseling among male and female with spinal cord and/or cauda equina injury. Part I. American Journal of Physical Medicine 57:107-122.

ComarR EA, Vigue MS 1978 Sexual counseling among male and female patients with spinal cord and/or cauda equina injury. Part II. American Journal of Physical Medicine 57:215-222.

ERTEKIN C, REEL F 1976 Bulbocavernosus reflex in normal men and in patients with neurogenic bladder and/or impotence. Journal of the Neurological Sciences 28:1-15.

HoHMANN GW 1972 Consideration in management of psychosexual readjustment in cord injured male. Rehabilitation Psychology 19:50-58.

KaRACAN I, HuRSCH CJ, Williams RL, et al. 1972 Some characteristics of nocturnal penile tumescence in young adults. Archives of General Psychiatry 26:351-356.

KARACAN I, Williams RL, ThORNBY JI 1975 Sleep related penile tumescence as a function of age. American Journal of Psychiatry 132:932-937.

KARACAN I, SAlIS PJ, WARE JC, et al. 1978 Nocturnal penile tumescence and diagnosis in diabetic impotence. American Journal of Psychiatry 135:191-197.

KENEPP D, GONICK P 1979 Home monitoring of penile tumescence for erectile dysfunction. Urology 14:261-264.

LEYSON JFJ, POWELL RB 1982 Comparative study of two nocturnal penile tumescence monitors in the diagnosis of impotence. Journal of the Medical Society of New Jersey 79:647-650.

LEYSON JFJ: Effects of prostatectomy on sexual functioning and the use of penile prosthesis. J. Sex Res. (In press)

Marshall P, Morales A, SuRridge D 1981 Unreliability of nocturnal penile tumescence recording and MMPI profiles in assessment of impotence. Urology 17:136-139.

Woolf CM 1968 Principles of Biometry, pp. 98-112, Van Nostrand Co; Princeton, N.J. 